\title{
SOCIO-ECONOMIC PROBLEMS OF THE RUSSIAN CONSTRUCTION OF ART NOUVEAU PERIOD (ON THE EXAMPLE OF A.L. LISHNEVSKY'S ACTIVITY)
}

\author{
Aleksandr I. Chepel \\ State Marine Technical University of Saint Petersburg, Saint Petersburg, Russian Federation
}

\begin{abstract}
The author studies the specifics of Russian architect's work on the example of the activity of prominent architect of Art Nouveau period A.L. Lishnevsky (1868-1942). The special attention is paid to the architect's relations with the authorities, contractors and workers, as well as with customers and colleagues. The author shows the opinion of citizens about the activities of an architect as a builder and businessman, reveals the main socio-economic problems which the architect faced from the moment of inception and approval of the project prior to its actual implementation. The author attempts to trace the mechanism of professional networking in the architecture environment of that time, and to reveal the peculiarities of private architectural bureaus ("offices"). The attention is paid to the assessment by the architect of their own professional activity.

A.L. Lishnevsky's activity is a good example of architect's work in the construction business. A native of the city of Kherson, he received the metropolitan education at the Art Academy, then for over six years (1895-1901) he worked as a municipal architect in Elisavetgrad (Kirovograd, since 2016 - Kropivnytsky) during the period of rapid economic and cultural growth of the town. After 1901 and up to 1917 he was actively engaged in municipal and private construction in the capital of the Russian Empire, Saint Petersburg.

The relevance of the topic is determined by the fact that the Art Nouveau period architect worked in capitalism construction market, and was forced to deal with issues similar to those that the architects of our time solve. The study is based on materials from Russian archives and periodicals of late $19^{\text {th }}$ - early $20^{\text {th }}$ century.

Key words: Art Nouveau period, architect A.L. Lishnevsky, private architectural bureau ("office"), construction legislation of the Russian Empire, construction of Elisavetgrad, construction of Saint Petersburg.

Citation. Chepel A.I. Socio-Economic Problems of the Russian Construction of Art Nouveau Period (on the Example of A.I. Lishnevsky's Activity). Vestnik Volgogradskogo gosudarstvennogo universiteta. Serija 4, Istorija. Regionovedenie. Mezhdunarodnye otnoshenija [Science Journal of Volgograd State University. History. Area Studies. International Relations], 2017, vol. 22, no. 3, pp. 96-111. (in Russian). DOI: https://doi.org/10.15688/jvolsu4.2017.3.9.
\end{abstract}

УДК 94(47).083

ББК $63.3(2) 5$
Дата поступления статьи: 28.09.2016

Дата принятия статьи: 11.01.2017

\section{СОЦИАЛЬНО-ЭКОНОМИЧЕСКИЕ ПРОБЛЕМЫ РОССИЙСКОГО СТРОИТЕЛЬСТВА ПЕРИОДА МОДЕРНА (НА ПРИМЕРЕ ДЕЯТЕЛЬНОСТИ А.Л. ЛИШНЕВСКОГО)}

\footnotetext{
Александр Иванович Чепель

\begin{abstract}
Санкт-Петербургский государственный морской технический университет, г. Санкт-Петербург,
\end{abstract} Российская Федерация

Аннотация. В статье на примере деятельности видного архитектора периода модерна А.Л. Лишневского (1868-1942) исследуется специфика работы российского архитектора этого периода в качестве строителя. Изучаются особенности взаимоотношений архитектора с представителями власти, со строительными подрядчиками и рабочими, с заказчиками, со своими коллегами. Продемонстрировано мнение горожан о деятельности
} 
архитектора как строителя и бизнесмена. Автор выявляет основные социально-экономические проблемы, которые встречались на пути архитектора от момента создания и утверждения проекта до его осуществления в натуре. Делается попытка проследить механизм образования профессиональных связей в архитектурной среде того времени, выявить особенности функционирования частных архитектурных бюро («кабинетов»). Уделяется внимание оценке самим архитектором собственной профессиональной деятельности.

Деятельность А.Л. Лишневского является показательным примером функционирования архитектора в строительном бизнесе. Уроженец города Херсона, он получил столичное образование в Академии художеств, затем более шести лет (1895-1901) работал городским архитектором в Елисаветграде (Кировоград, с 2016 г. - Кропивницкий) в период бурного экономического и культурного роста этого города. После 1901 г. он вплоть до 1917 г. активно занимался муниципальным строительством и частной строительной практикой в столице Российской империи - Санкт-Петербурге.

Актуальность рассматриваемой темы определяется тем, что архитектор периода модерна работал в условиях капиталистического строительного рынка и вынужден был решать вопросы, подобные тем, которые решают архитекторы в наше время. Исследование основано на материалах российских архивов и периодических изданий конца XIX - начала XX века.

Ключевые слова: период модерна, архитектор А.Л. Лишневский, частное архитектурное бюро («кабинет»), строительное законодательство Российской империи, строительство Елисаветграда, строительство Санкт-Петербурга.

Цитирование. Чепель А. И. Социально-экономические проблемы российского строительства периода модерна (на примере деятельности А.Л. Лишневского) // Вестник Волгоградского государственного университета. Серия 4, История. Регионоведение. Международные отношения. -2017. - Т. 22, № 3. - С. 96-111. - DOI: https://doi.org/10.15688/jvolsu4.2017.3.9.

Вопросы о предназначении архитектора, о качествах, необходимых ему для успешного функционирования в своей сфере деятельности, о взаимоотношениях со специалистами различных строительных профессий, с заказчиками, властью, коллегами и обществом не теряют остроты на протяжении всей истории архитектуры как сферы человеческой деятельности [23, с. 290]. С конца ХІХ в. до трагических событий 1917 г. российский архитектор работал в условиях динамичной трансформации строительного дела. Бурный рост капиталистической экономики вызывал к жизни новые типы сооружений, архитектурная практика осваивала новые конструкции и строительные материалы, в обществе неуклонно рос интерес к различным аспектам зодчества. Все это требовало от архитекторов быть готовыми достойно отвечать на вызовы времени, решать доселе небывалые задачи [3, с. 5-7]. Архитектор в современной России поставлен в сходные условия. По этой причине актуально изучить опыт более чем вековой давности, чтобы на примере исторического прошлого попытаться найти возможные пути решения важнейших современных социально-экономических проблем, возникающих в процессе архитектурной практики - как в ходе воплощения в жизнь своего проекта выстраивать отношения с заказ- чиком, с властью, со строительными специалистами, с коллегами и обществом. В настоящей статье мы попытаемся выяснить, какие ответы на эти вопросы находили российские архитекторы периода модерна. В качестве примера рассмотрим деятельность значительного мастера изучаемого периода - Александра Львовича Лишневского (1868-1942).

Успешному выходу на конкурентный строительный рынок для выпускников Академии художеств в определенной степени могла способствовать обязательная практика под руководством старших коллег. А.Л. Лишневский в 1892-1893 гг. работал в качестве помощника на постройках Б.И. Гиршовича и удостоился от него положительных отзывов. Но студент не ограничился работой под присмотром опытного мастера, а стремился самостоятельно выйти на столичный строительный рынок. В мае 1893 г. А.Л. Лишневский, пребывая еще в статусе академиста (то есть до получения диплома), затребовал и получил в Академии художеств временное свидетельство на право производства строительных работ $[17$, л. 46,50$]$ и вскоре спроектировал и построил каменные двухэтажные служебные здания в одном из петербургских домовладений (Волоколамский пер., 3).

Получив осенью 1894 г. диплом, уже обзаведшийся семьей архитектор был озабочен 
поиском работы и просил Совет Академии художеств зачислить его в число кандидатов на получение места архитектора в Ферганскую область, где открылась вакансия младшего инженера. Ожидание ответа от тамошнего губернатора затянулось, и А.Л. Лишневский в апреле 1895 г. уведомил Академию художеств: «...вследствие долговременного отсутствия ответа на прошение мое Ферганскому губернатору, я получил другую должность и вынужден отказаться от предложенной мне должности младшего инженера». «Вынужденный материальными условиями», архитектор поступил на службу городским архитектором Елисаветграда [17, л. 81, 95].

В марте 1895 г. А.Л. Лишневский приступил к исполнению обязанностей городского архитектора Елисаветграда [4] (Кировоград, с 2016 г. - Кропивницкий). На недавнего выпускника Академии художеств были возложены разнообразные обязанности. Он выполнял проектные и строительные работы по заказу города; проверял соответствие законодательству проектов частных построек, поданных для утверждения в Городскую управу (городское правительство), и контролировал проводившиеся по этим проектам строительные работы; проводил экспертизы существующих построек на предмет их возможного сохранения и реконструкции; руководил работами по благоустройству города. Как архитектор указывал впоследствии, за этот период своей деятельности он построил «весьма много общественных и частных зданий и дорожных сооружений» [18, л. 11 об.], при этом исполнение служебных обязанностей давалось подчас «весьма тяжело» [17, л. 95].

Рекомендации, поступавшие от городского архитектора на этапе утверждения чертежей, играли существенную роль в смысле общественной безопасности предполагаемых построек. Так, в 1896 г., при рассмотрении проекта здания центральной электрической станции городской железной дороги (трамвая), представленного представителем подрядчика, получившего право на проведение этих работ, А.Л. Лишневский и городской инженер С.И. Буйницкий сфокусировали внимание городского правительства на слабой проработке проекта в отношении прочности постройки. Они потребовали внести в чертежи следующие дополнения: согласовать глу- бину заложения фундамента с глубиной материка; для большей прочности сделать стены подвального этажа не сводчатыми, а сплошными; усилить перекрытия больших пролетов дополнительными балками; предусмотреть укрепление некоторых конструкций железными стяжками; устроить отдельные фундаменты под паровые котлы и машины [6]. В том же году городской архитектор, зафиксировав случаи падения нескольких телефонных столбов, сделанных из сосны, предложил, во избежание подобных случаев, угрожавших общественной безопасности, в дальнейшем, заменить эти конструкции на дубовые или железные [5].

В ходе выполнения служебных обязанностей А.Л. Лишневский нередко вынужден был вступать в конфликты с домовладельцами, стремившимися самовольно изменить облик своих домов. Так, в феврале 1897 г. мещанин Ф. Зеленщенко обратился с ходатайством об оставлении на его доме выступов, не предусмотренных проектом, но городской архитектор воспротивился этому нарушению закона. Он уведомил Городскую управу, что, несмотря на его требование не отступать от утвержденного проекта, домовладелец «изменил фасад дома, построив, с целью расширения внутреннего пространства своих лавок, входы наружные вместо внутренних, причем сделал значительный захват тротуара под выступы». При этом А.Л. Лишневский, заметив нарушение, вероятно, предложил домовладельцу компромисс, от которого тот отказался: архитектор заявил на заседании городского правительства, что переделать выступы на внутренние входы «легко и не особенно дорого, но это не в интересах господина Зеленщенко». В результате в сохранении противоречивших законодательству выступов было отказано [7]. В конце 1897 г. по результатам осмотра усадьбы отставного рядового С.И. Шкукова, просившего разрешить эксплуатировать существовавшую на участке кузницу, городской архитектор проявил принципиальность и запретил производить кузнечные работы, требуя построить новую кузницу по причине опасности старой постройки в пожарном отношении [8].

Происходили столкновения у городского архитектора и с представителями городского самоуправления. Город задумал построить женскую гимназию, было выбрано удоб- 
ное место, причем А.Л. Лишневский довольно придирчиво искал участок для постройки. В июне 1898 г. он докладывал городскому руководству, что лично осмотрел выбранный участок и пришел к выводу, что, «судя по тем капитальным постройкам, которые окружают это место, нет оснований предположить, что грунт его был не прочен». А.Л. Лишневский не удовлетворился простым аналитическим выводом. Осмотрев район предполагаемой постройки, архитектор обследовал грунт и доложил, что «материк означенного места - песчаный и расположен очень неглубоко от поверхности земли, а потому он с уверенностью может сказать, что место это, в смысле прочности грунта, вполне может быть признано надежным для постройки здания гимназии». Выбранный им участок был утвержден, А.Л. Лишневский составил проект [9]. Однако вскоре группа гласных (депутатов) Елисаветградской думы выступила с инициативой строить в другом месте. Городской архитектор доказал, что вновь предложенное место никак не годится для женской гимназии: «В то время как предположенный для постройки участок со всех сторон будет окружен улицами, участок, предлагаемый ныне, - непосредственно примыкает к казармам с населением в три батальона солдат и к базару не без лошадей», и не годится, если девушки будут учиться в таком окружении. Кроме того, изначальное место - «ровная площадка с малым уклоном и удобная для постройки такого большого здания», тогда как значительный уклон нового участка существенно усложнит работы и приведет к удорожанию строительства, а почва предлагаемого гласными участка «весьма загрязнена бывшими там, весьма примитивного устройства, конюшнями без полов» [11]. Упорство архитектора принесло плоды: инициатива группы депутатов была отклонена, и гимназию построили на задуманном изначально месте.

Вскоре назрел новый конфликт, который в итоге привел к увольнению А.Л. Лишневского с должности городского архитектора. На него подали жалобу местные строительные подрядчики, обвиняя архитектора в том, что он берет частные заказы в ущерб служебным обязанностям, а также выказывает при выборе подрядчиков «чрезмерную и излиш- нюю придирчивость». В процессе разбора жалоб у архитектора нашлись заступники некоторые елисаветградские домовладельцы: «Город наш не настолько велик, чтобы мог дать достойную практику частным архитекторам и привлечь их на жительство, а граждане наши в большинстве случаев также не настолько богаты, чтобы вызывать специально для своих построек архитекторов из других городов», поэтому нужно только приветствовать, что зодчий со столичным образованием обосновался здесь и в свободное время берется за частные заказы, тем самым как зарабатывая на жизнь (что важно с учетом не слишком большого жалованья), так и экономя деньги местных домовладельцев. Поэтому лишение городского архитектора частной практики никому «не принесет никакой пользы», тем более что городской архитектор, «вращаясь по прямым своим служебным обязанностям исключительно в сфере разных ремонтов казарм, лавок, мостовых и других тому подобных работ, не только не будет прогрессировать в своей специальности, но даже разучится и тому, что знал раньше - ведь архитектура как искусство требует постоянной практики». Что же касается жалоб подрядчиков, то в отношениях с ними архитектор всегда проявлял «одинаковую строгость и требовательность в интересах качества постройки», а цены на свои услуги устанавливал «намного ниже цен», которые приходилось платить прежде, «отдавая себя на произвол подрядчиков». В результате А.Л. Лишневский «для частных лиц принес неоцененную пользу, ознакомляя и разъясняя домовладельцам, что значит “хорошо сделано, хорошо построено"» [12]. Таким образом, становится понятной нелюбовь подрядчиков к городскому архитектору: теперь они не могли завышать цены, пользуясь неосведомленностью заказчиков. А.Л. Лишневский потребовал разбирательства по существу, но вскоре подал в отставку и уехал в Санкт-Петербург. Его преемнику повысили жалованье почти вдвое (до 2400 рублей в год), но запретили заниматься частной практикой. По этому поводу Елисаветградская городская дума постановила, что совмещение в одном лице производителя частных построек и «доверенного агента городского управления, 
на обязанности которого лежит контроль за правильностью возведения частных построек в строительном и пожарном отношениях, не может быть признано вообще явлением нормального порядка вещей» [10].

По прибытии в столицу Российской империи А.Л. Лишневский, по его собственным словам, «занялся дальнейшим художественным своим развитием» [17, л. 95 об.], «главным образом, участвуя в архитектурных конкурсах» [18, л. 11 об.], один из которых послужил своего рода трамплином, с которого архитектор успешно стартовал в строительном деле Санкт-Петербурга. В 1903 г. он занял призовое место в конкурсе проектов Дома городских учреждений (Садовая ул., 55-57 - Вознесенский пр., 4042), а в 1904-1906 гг. создал рабочий проект и осуществил постройку этого крупного многофункционального общественного здания. Специалисты Техническо-строительного комитета Министерства внутренних дел, где согласовывался проект, признавали его сложность [13, л. 10 об.], поэтому неудивительно, что А.Л. Лишневский привлек помощников. Впоследствии он вспоминал, что участниками составления рабочего проекта и осуществления строительства были четыре архитектора, но фамилии их не указал [26, л. 3 об.]. Удалось выяснить, что среди них был П.П. Светлицкий [33, с. 165], еще не закончивший обучение в Высшем художественном училище при Академии художеств, но получивший 2 апреля 1904 г. разрешение на производство строительных работ [25, л. 20]. Возможно, на этапе возведения постройки в работах принимал участие студент того же учебного заведения С.Я. Турковский, указывавший, что с 1906 г. работал помощником на постройках А.Л. Лишневского [30, л. 18 об.].

Через полтора года после окончания постройки стены пошли трещинами и была создана специальная комиссия, перед которой должен был держать ответ ответственный строитель - А.Л. Лишневский. Предварительный осмотр Дома городских учреждений, в ходе которого обнаружились «несомненные признаки, дающие впечатление не совсем правильной постройки», выявил наличие 60 трещин различного размера. Все трещины были не только запротоколированы, но каждая из них зафиксирована «фотографическим путем»-чтобы скрыть их, замазать было уже невозможно. В ходе обхода здания один из членов комиссии, гласный Петр Фокин, возмущенный обилием трещин, заметил: «Я бы такому архитектору не позволил и будку выстроить!». В ответ ответственный строитель «вспыхнул гневом», бросив: «Скорее можно издохнуть, чем этот дом обвалится!», - отпустив затем «тирады еще более оскорбительного свойства». Далее «разговор принял крайне обостренный оборот», распаленный архитектор схватил городского депутата за борт пальто; тот, отражая нападение, в свою очередь ухватился за костюм обидчика. Тогда А.Л. Лишневский «пустил в ход приемы японского джиу-джитсу и французского бокса» и нанес Фокину удар кулаком в живот. Остальные члены комиссии, «дабы не допустить переход пикировки в драку», вмешались в ссору и своевременно погасили ее. Журналисты тут же отреагировали на этот инцидент серией статей и фельетонов. Заголовки вопрошали: «Как спасти Дом городских учреждений от разрушения?». Горожан запугивали, насколько небезопасно жить в домах, которые строят «из манной крупы, клейстера, непринятых драматических произведений и прочего мусора»; пугали домовладельцев-заказчиков, что отныне при общении с архитекторами следует обезопасить себя, обзаведясь «бронированным фургоном». Рассматривалась проблема и под более серьезным углом зрения: как городские власти, имевшие на службе квалифицированных техников, приняли постройку, пропустив при этом столь существенные недостатки, что сейчас здание грозит разрушением? В итоге встревоженная Городская управа образовала еще одну комиссию, в которую вошли авторитетные петербургские архитекторы. Комиссия вновь скрупулезно осмотрела здание и вынесла решение: «общее состояние дома не дает поводов к опасению в смысле безопасности», а образование трещин объясняется «неравномерностью осадки и разновременностью возведения частей здания при сложности плана, обширности самой постройки и затруднитель- 
ности условий производства работ». Городское правительство сформировало техническую комиссию (куда вошел и А.Л. Лишневский), под наблюдением которой и были произведены необходимые ремонтные работы [24], и с тех пор здание не вызывает опасений в смысле прочности постройки.

Как видим, А.Л. Лишневский сумел доказать городским властям и общественности свое умение проектировать и строить прочные дома. Тем не менее газетные опасения о возможности возведения многоэтажных зданий из различного «мусора» не были журналистским преувеличением. Летом 1909 г. в Санкт-Петербурге обрушилась часть строящегося дома братьев Залеманов (Разъезжая ул., 26-28), погребя под собой 11 рабочих. Эта строительная катастрофа получила большой резонанс, ее обсуждали, в частности, на заседании Петербургского общества архитекторов, где выступил и А.Л. Лишневский, который указал, что фундамент рухнувших корпусов был «наложен на сухом мусоре». Далее, когда в процессе обсуждения выявились два основных фактора строительных катастроф - отсутствие надлежащего властного надзора за правильностью постройки и использование негодного материала вкупе с непрофессиональными техническими решениями, А.Л. Лишневский привел пример: «Я лично, в своей практике, посылал телеграмму участковому технику с просьбой приехать, так как не мог сам сладить со своим клиентом» [28, л. 201, 211]. Здесь архитектор поднял острый вопрос о своего рода «заколдованном треугольнике»: заказчик - архитектор (ответственный строитель) - техник городского надзора (участковый архитектор). Проблема заключалась в том, что юридическую ответственность за прочность постройки, грамотное применение конструкций и качество материала нес ответственный строитель, приглашенный домовладельцем-заказчиком для составления проекта и возведения дома. Городской техник отвечал только за соответствие возводимой постройки в основных конструктивных частях утвержденному проекту и не имел права проверять качество материала. Домовладелец же формально не должен был вмешиваться в процесс строи- тельства, но на деле нередко брался руководить подрядчиками и рабочими через голову ответственного строителя, стремясь поскорее и дешевле построить дом с целью его скорейшей продажи или получения ссуды под залог этой недвижимости. В этих случаях часто использовался негодный материал, закупленный по демпинговым ценам. Так случилось в доме Залеманов, где ответственный архитектор был фактически отстранен домовладельцем от работ (очевидно, за вознаграждение), служа лишь своего рода ширмой для манипуляций на стройплощадке. Подобный расклад фиксировался в столичном строительстве не однажды. Так, 17 июля 1912 г. рухнула часть флигеля строящегося петербургского дома И.Г. Торкачева (Лиговский пр., 107), погребя двух рабочих. Оказалось, что домовладелец не только поставлял на стройплощадку все стройматериалы в соответствии со своими представлениями об их качестве, но часто вмешивался в отдаваемые ответственным архитектором В.Д. Николя распоряжения и даже «отменял таковые, давая взамен их свои, и преследовал при этом наивозможную экономию, вследствие чего на постройку применялся материал не вполне доброкачественный». Фатальным стало распоряжение домовладельца прорубить проем для лифта, вследствие чего ослабленная конструкция вскоре рухнула [21, л. 7 об.]. При такой острой ситуации в частновладельческом строительстве не кажется позерством семейное воспоминание о поведении А.Л. Лишневского на стройке, когда он проверял прочность кладки, нанося ей удар ногой [19].

Важным ресурсом в деле качественного строительства служили добросовестные сотрудники, и А.Л. Лишневский сумел сплотить вокруг себя достойную команду, выступая в качестве руководителя частного архитектурного бюро, «кабинета» [14, c. 19], в практике которого, насколько известно, не случалось строительных катастроф. Постоянными сотрудниками архитектора были А.Л. Берлин [15, с. 435] и С.Я. Турковский, исполнявший на многих постройках мастера ключевую роль производителя работ [32, с. 30-31]. В 1909-1914 гг. будущий 


\section{ИСТОРИЯ РОССИИ}

известный советский зодчий И.Г. Лангбард совмещал учебу в Высшем художественном училище при Академии художеств с «производственной и проектировочной практикой» на постройках А.Л. Лишневского [16, л. 12]; его же помощником некоторое время выступал другой в будущем известный архитектор, А.Е. Белогруд [29, с. 10]. Между архитекторами «круга Лишневского» нередко устанавливались как деловые, так и родственные, и дружеские связи. С.Я. Турковский в 1913 г. стал восприемником сына П.П. Светлицкого [31, с. 32], а позже женился на дочери А.Л. Лишневского [33, с. 166]. П.П. Светлицкий выступал на конкурсах архитектурных проектов в соавторстве с С.Я. Турковским и А.Л. Берлиным [31, с. 28]. В 1914 г. соавторами на одном из конкурсов были А.Л. Берлин и С.Я. Турковский [1], а в 1915 г. - И.Г. Лангбард, С.Я. Турковский и А.Л. Берлин [2]. Налаженные связи не прерывались подчас долгое время: в 1922-1941 гг. С.Я. Турковский совместно с И.Г. Лангбардом участвовал в проектировании многих известных зданий в Киеве и Минске [32, с. 33]. Не случайно одним из важнейших достижений А.Л. Лишневского после его смерти признавалось то, что он воспитал «на своей практической работе многочисленные кадры высококвалифицированных строителей» [33, c. 177]. С вниманием относился архитектор и к рабочим: «Я лично по имени не знаю рабочих, но сам он придет, то по физиономии я узнаю, с кем имею дело. Надо быть архитектором, который из бинокля смотрит на свою постройку, чтобы не знать рабочих, а архитектор, который трудится, знает их» [27, л. 159 об. -160.$]$.

Российский (особенно столичный) архитектор изучаемого периода в условиях интенсивного строительства получал возможность довольно быстро улучшить свое материальное положение и во многом по этой причине находился под прицелом общественной критики. Столичная газета в 1907 г. зло заявляла: «Ни одна профессия... не создает таких чудес, такого быстрого чисто феерического превращения бедняка в богача, как занятие зодчеством. Зодчим считается и какой-нибудь Петр Петрович Петров через год или два по окончании Академии художеств, Института гражданских инженеров или военно-инженерных школ и, заполучив одну-две постройки, не замедлит попутно и себе выстроить домик этажей в пять где-нибудь в Забытом переулке. И это при условии, что два-три года тому назад он был гол как сокол» [22]. А.Л. Лишневский за годы работы в российской столице обзавелся собственными доходными домами, к строительству первого из которых он приступил в 1908 г. [34, с. 84-85]. Выступая одновременно в качестве архитектора и домовладельца, А.Л. Лишневский подчас допускал некоторые отступления от строительного законодательства. Так, в 1915 г. на своем плотно застраиваемом участке по Колокольной ул., 8 он несколько превысил высоту венчающего парапета; один воротный проезд сделал слишком узким, а вместо второго устроил гараж; в некоторых конструкциях применил пожароопасные материалы. Все эти нарушения были запротоколированы, и архитектор-домовладелец обязался их устранить [20]. По крайней мере до 1916 г. тянулось дело о нарушениях на другом столичном участке А.Л. Лишневского по Широкой ул. (ул. Ленина, 41), где также постройка несколько превысила законные параметры, а один из дворовых проездов был занят не предусмотренными проектом помещениями [34, с. 91-92].

Активная деятельность А.Л. Лишневского как архитектора, занимающегося частной практикой, была прервана революционными событиями 1917 года. Приобретенный им богатый опыт проектирования и возведения зданий оказался вновь востребован в полной мере только в 1930-е гг., когда в Ленинграде стартовало масштабное строительство. Он, наряду с другими своими коллегами, формировавшимися как профессионалы в краткий период модерна, чрезвычайно насыщенный не только художественными идеями, но также техническими, организационными и правовыми изменениями в строительном деле, получил такую богатую разностороннюю подготовку, которая оказалась актуальна и в новых социально-политических условиях. Остается сожалеть, что политические события на полтора десятилетия прервали развитие того мощного отечественного архитектурно-строительного потенциала, который в полной мере проявил себя в период модерна. 


\section{ПРИЛОЖЕНИЯ}

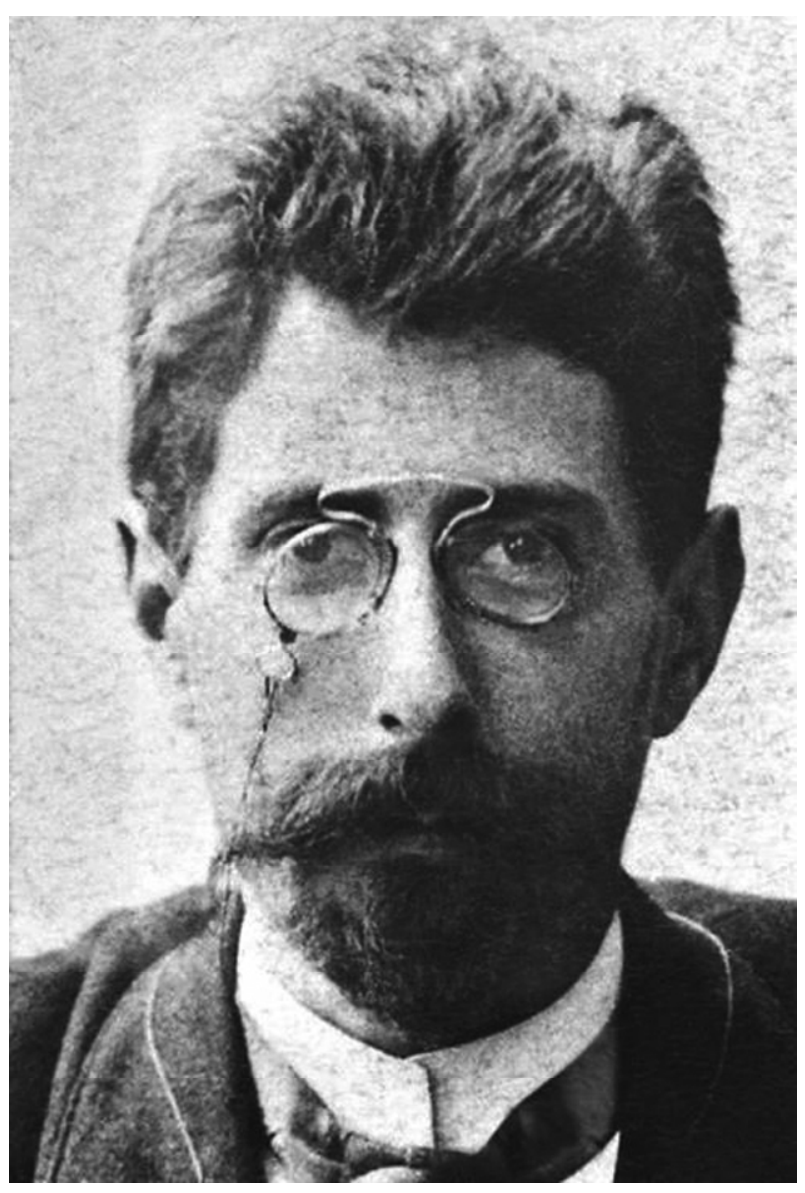

А.Л. Лишневский. Фото начала XX в.

Из семейного архива потомков архитектора

A.L. Lishnevsky. Photo of early $20^{\text {th }}$ century.

From the family archive of the architect's descendants 


\section{ИСТОРИЯ РОССИИ}

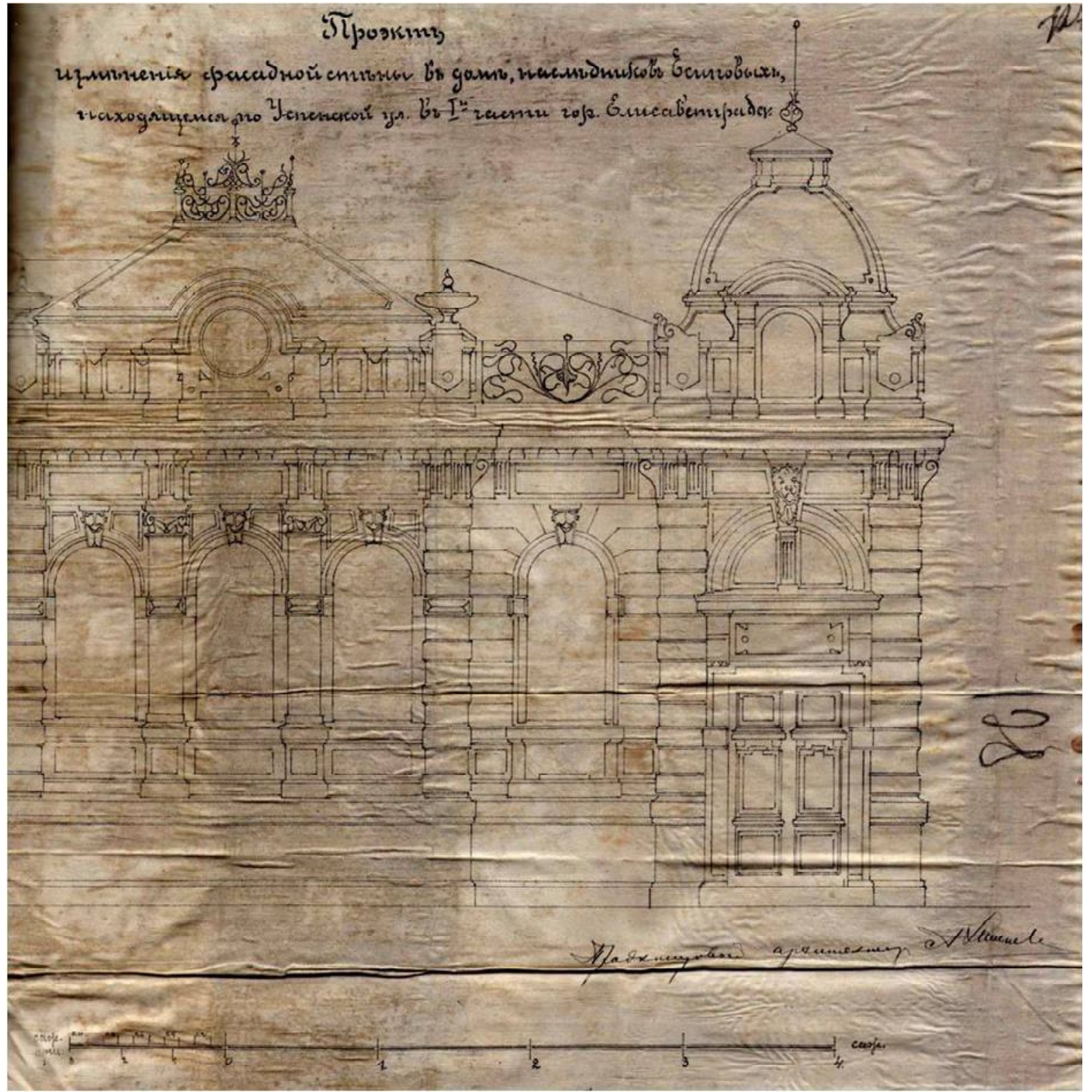

А.Л. Лишневский. Проект изменения фасадной стены в доме наследников Есиповых в Елисаветграде. 1901 г. Государственный архив Кировоградской области

A.L. Lishnevsky. The project of changing the front wall in the house of the Esipovs heirs in Elisavetgrad. 1901. State archive of the Kirovograd region 
А.И. Чепель. Социально-экономические проблемы российского строительства периода модерна

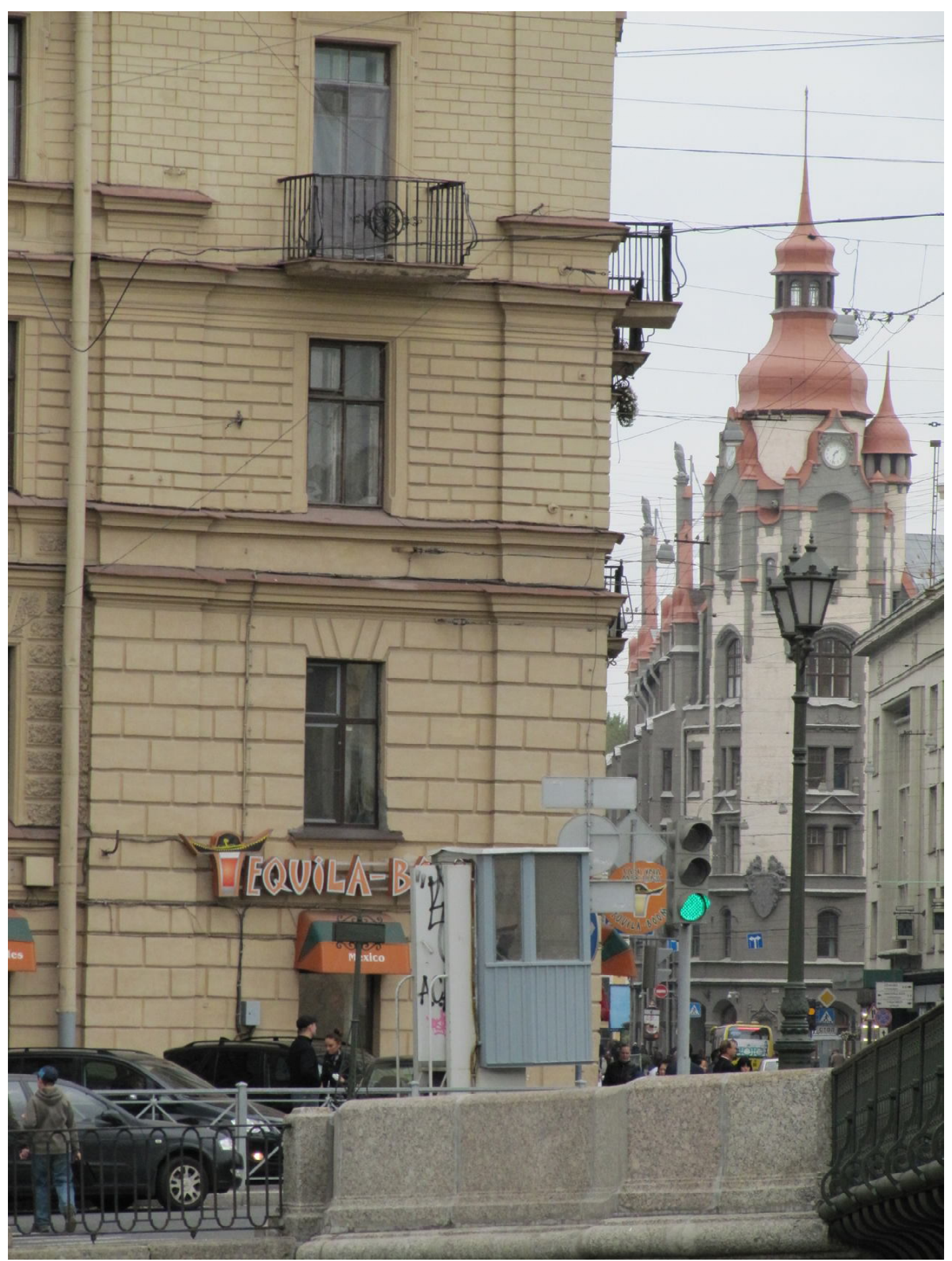

Дом городских учреждений в Петербурге.

Фото автора. 2015 г.

The house of city institutions in St. Petersburg.

Photo by the author, 2015 


\section{ИСТОРИЯ РОССИИ}

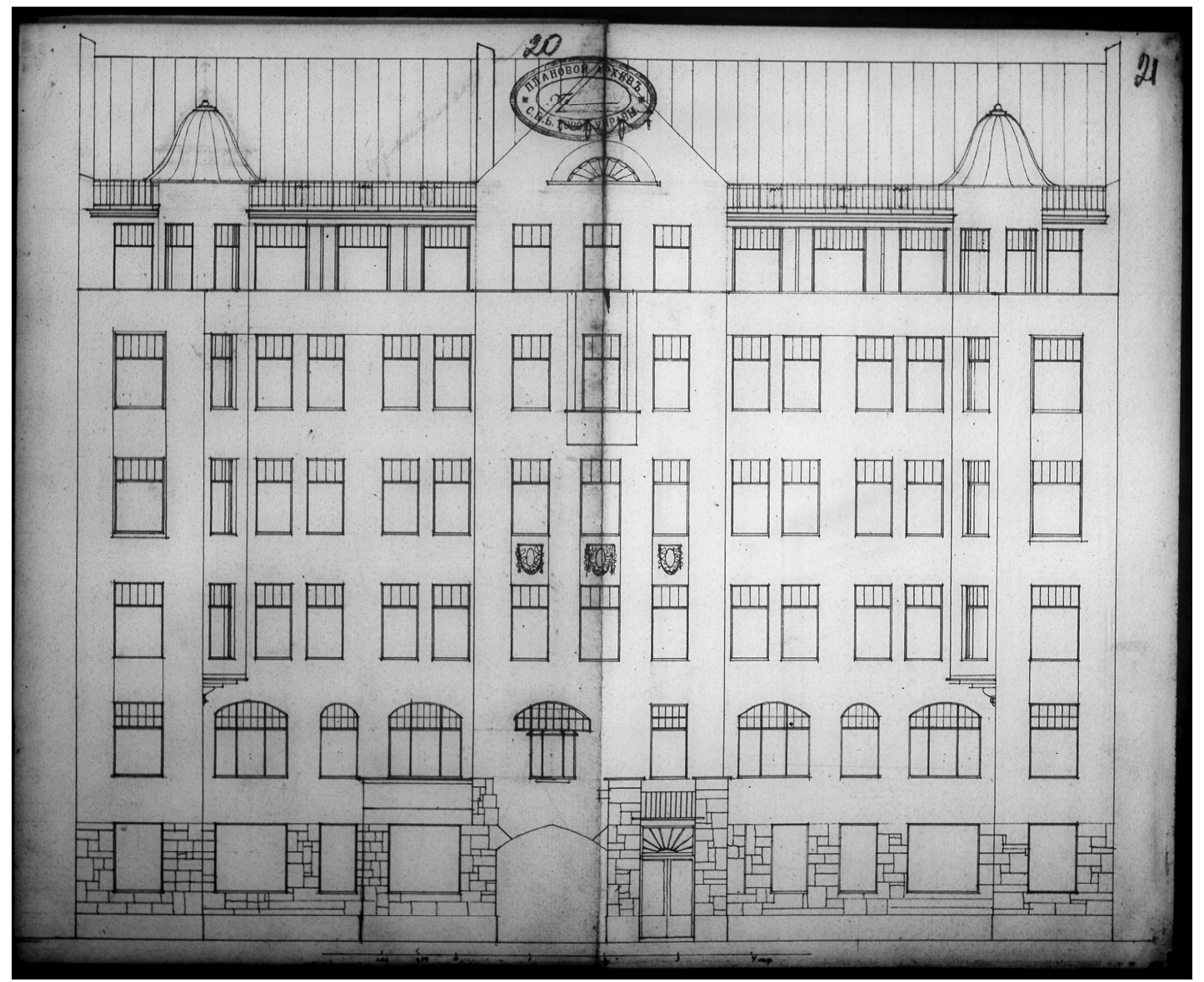

А.Л. Лишневский. Проект дома А.Л. Лишневского в Петербурге на Лахтинской ул., 24. 1910 г. ЦГИА СПб

The project of A.L. Lishnevsky's house in Saint Petersburg on 24, Lakhtinskaya St. 1910. Central State Historical Archive of St. Petersburg 


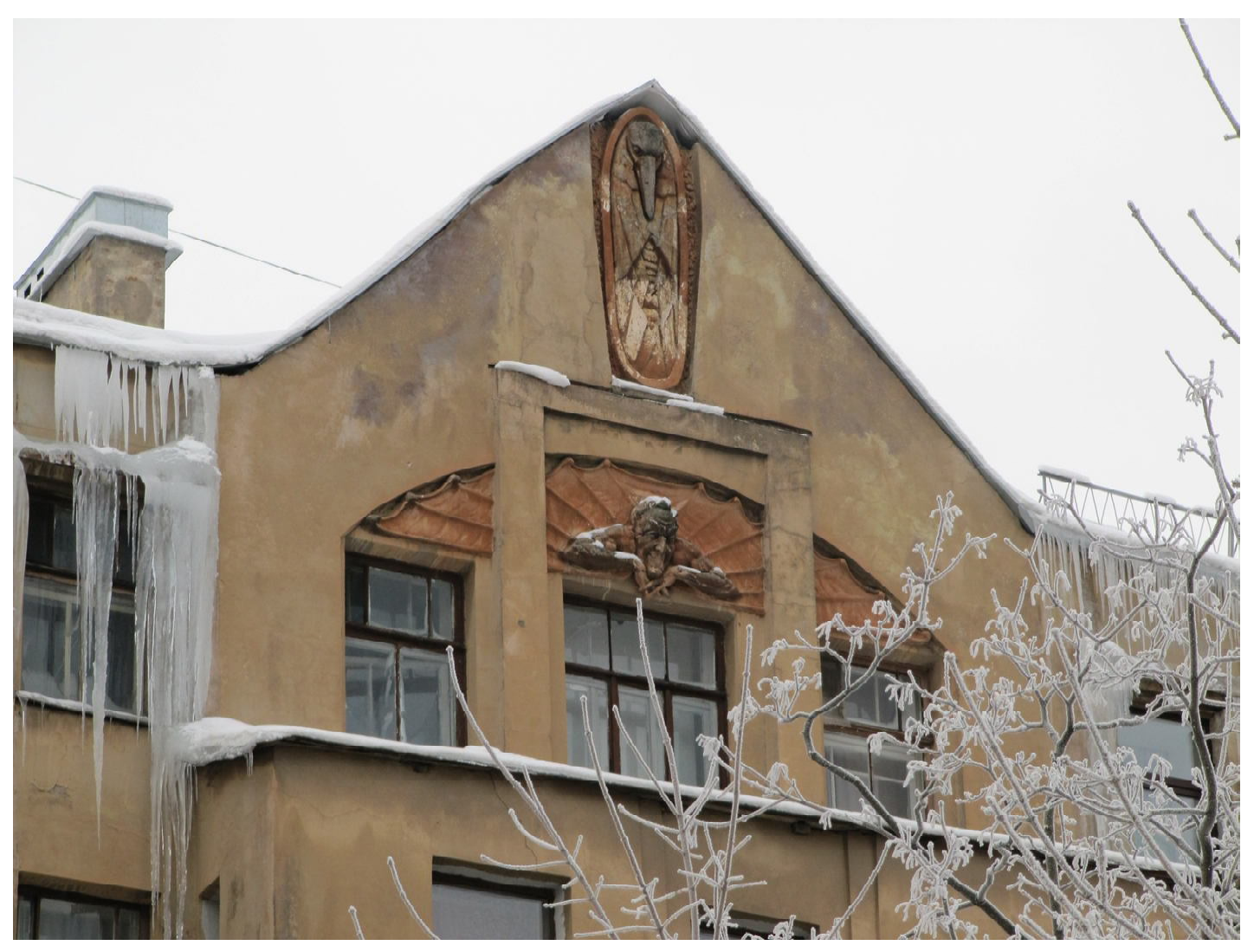

Деталь фасада дома на Лахтинской ул., 24.

Фото автора. 2010 г.

Detail of the house facade on 24, Lakhtinskaya St.

Photo by the author, 2010 


\section{ИСТОРИЯ РОССИИ}

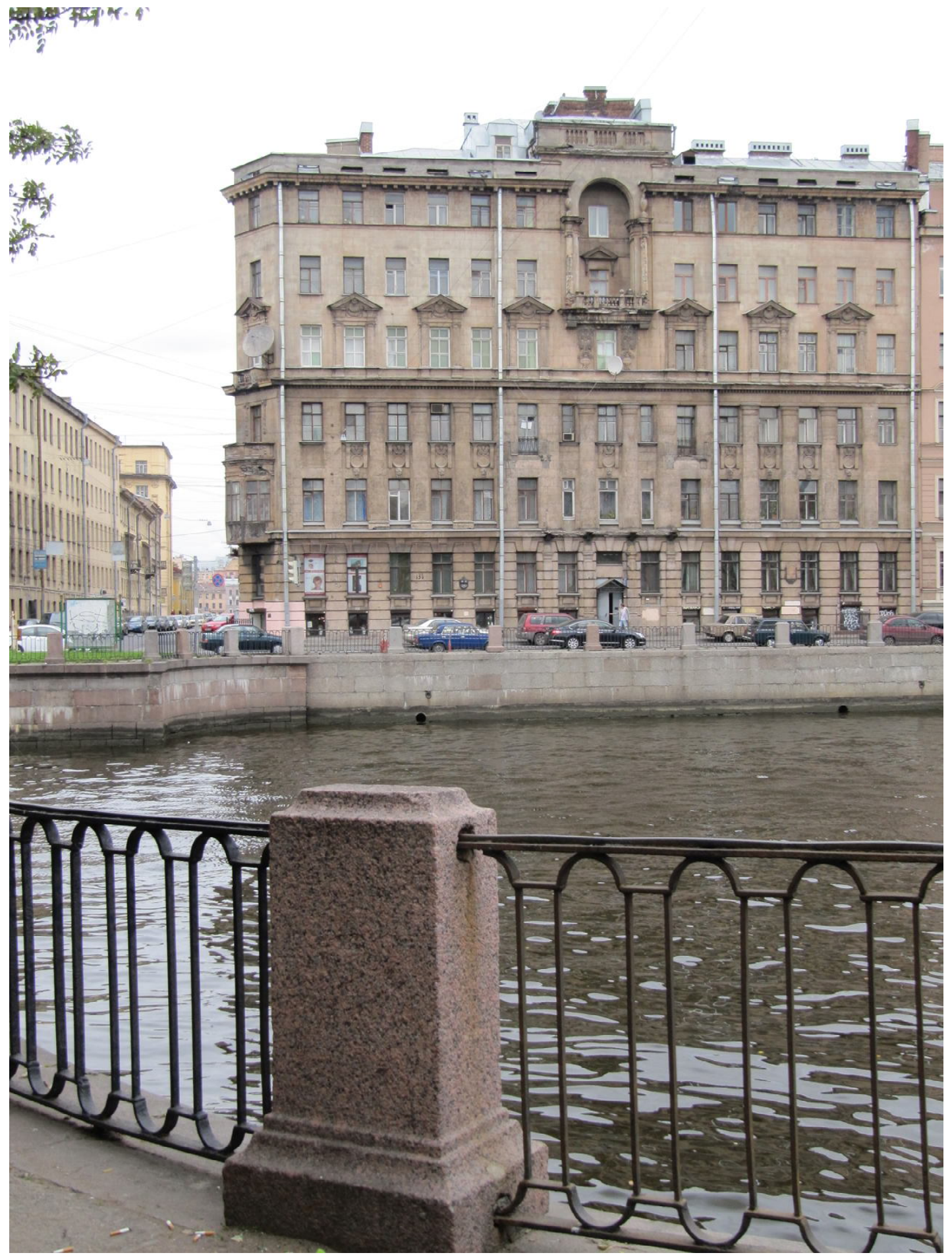

Дом Марголиных в Петербурге на наб. реки Фонтанки, 131. Архитектор А.Л. Лишневский. 1914 г. Фото автора. 2010 г.

The Margolins house in St. Petersburg on the Embankment of Fontanka River, 131. Architect A.L. Lishnevsky. 1914. Photo by the author, 2010 
А.И. Чепель. Социально-экономические проблемы российского строительства периода модерна

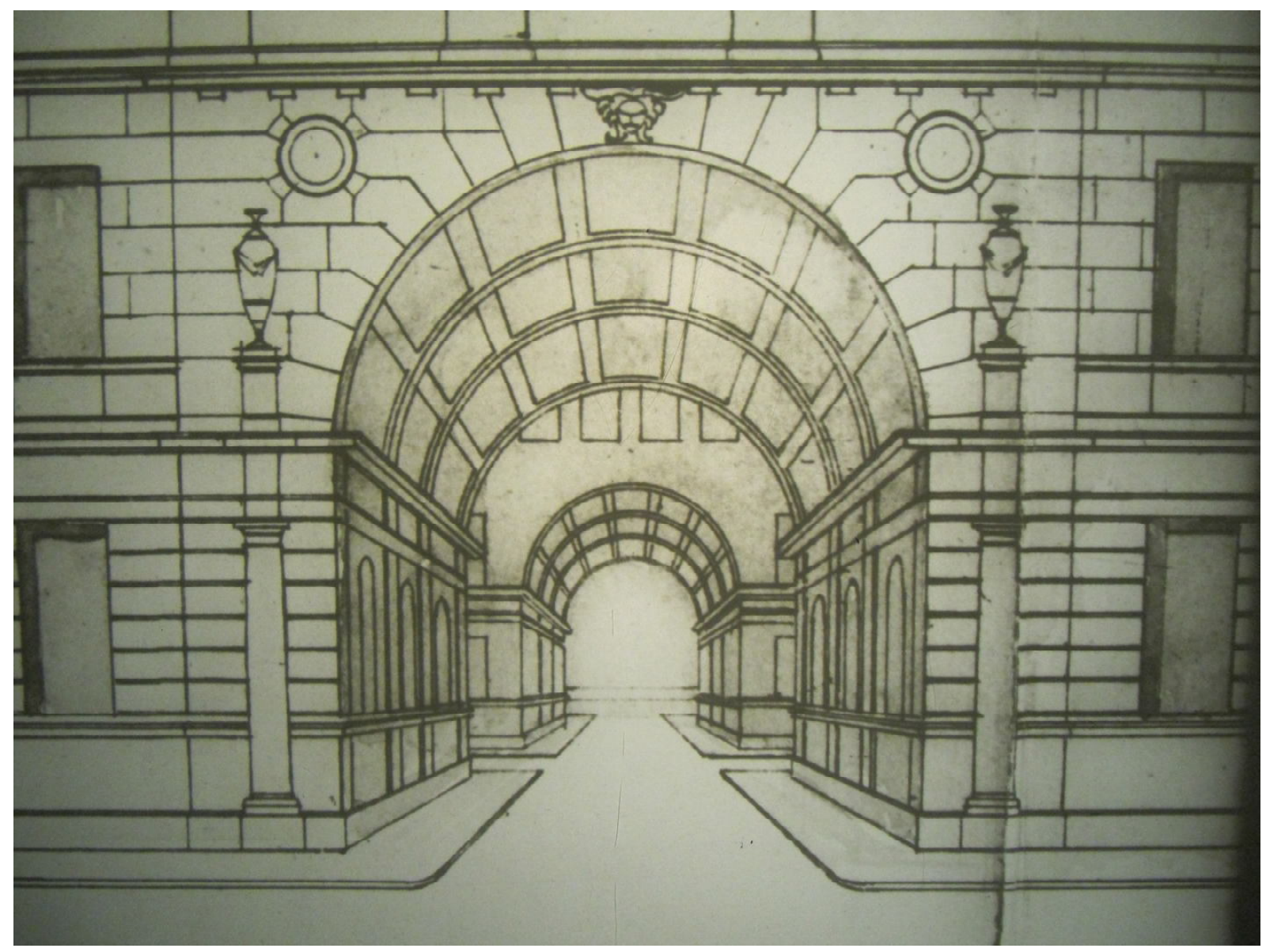

Деталь фасада дома А.Л. Лишневского в Петербурге на ул. Ленина, 41. Архитектор А.Л. Лишневский при участии С.Я. Турковского. 1912-1913 гг. ЦГИА СПб.

Detail of the facade of A.L. Lishnevsky's house in St. Petersburg on 41, Lenina St. Architect A.L. Lishnevsky with participation of S. Ya. Turkovsky. 1912-1913. Central State Historical Archive of St. Petersburg

\section{СПИСОК ЛИТЕРАТУРЫ}

1. Архитектурно-художественный еженедельник. - 1914. - 29 окт.

2. Архитектурно-художественный еженедельник. $-1915 .-5$ авг.

3. Борисова, Е. А. Русская архитектура конца XIX - начала XX века / Е. А. Борисова, Т. П. Каждан. - М. : Наука, 1971. - 239 с.

4. Ведомости Елисаветградского городского общественного управления. - 1895. - 19 марта.

5. Ведомости Елисаветградского городского общественного управления. - 1896. -5 июня.

6. Ведомости Елисаветградского городского общественного управления. - 1896. - 19 сент.

7. Ведомости Елисаветградского городского общественного управления. - 1897. - 8 апр.

8. Ведомости Елисаветградского городского общественного управления. - 1898. - 5 мая.
9. Ведомости Елисаветградского городского общественного управления. - 1898. - 2 авг.

10. Ведомости Елисаветградского городского общественного управления. - 1901. - 24 мая.

11. Ведомости Елисаветградского городского общественного управления. - 1901. - 1 июля.

12. Ведомости Елисаветградского городского общественного управления. - 1901. - 22 июля.

13. Дом городских учреждений // Российский государственный исторический архив (далее РГИА). -Ф. 1293. - Оп. 137. - Д. 31.

14. Казусь, И. А. Советская архитектура 1920-х годов: организация проектирования / И. А. Казусь. - М. : Прогресс-Традиция, 2009. $464 \mathrm{c}$.

15. Кириков, Б. М. Архитектура петербургского модерна. Особняки и доходные дома / Б. М. Кириков. - СПб. : Изд-во журн. «Нева», 2003. - 511 c. 
16. Лангбард И.Г.: личное дело // Научный архив Российской академии художеств (далее - НА РАХ). - Ф. 7. - Оп. 4. - Д. 132.

17. Лишневский А.Л.: личное дело // РГИА. Ф. 789. - Оп. 11. 1888 г. - Д. 107.

18. Лишневский А.Л.: личное дело // Центральный государственный исторический архив СанктПетербурга (далее - ЦГИА СПб.). - Ф. 513. Оп. 164. - Д. 1020.

19. МК в Питере. $-2015 .-9-16$ сент.

20. Об имуществе А.Л. Лишневского // ЦГИА СПб. - Ф. 513. - Оп. 156. - Д. 645.

21. О строительных нарушениях во дворе И.Г. Торкачева // ЦГИА СПб. - Ф. 513. - Оп. 156. Д. 309.

22. Петербургский листок. - 1907. 10 (23) июля.

23. Птичникова, Г. А. Прагматизация архитектурной профессии в условиях современного проектного рынка / Г. А. Птичникова // Архитектура в диалоге с человеком. - М. : УРСС/КомКнига, 2012. C. 290-304. 22 янв.

24. Санкт-Петербургские ведомости. - 2016. -

25. Светлицкий П.П.: личное дело // РГИА. Ф. 789. - Оп. 12. - Д. И-65.

26. Совещание с архитекторами Ленинграда. 1937 г. // Центральный государственный архив СанктПетербурга. -Ф. 7384. - Оп 18. - Д. 293.

27. Стенографические отчеты заседаний Петербургского общества архитекторов. 1908 г. // ЦГИА СПб. -Ф. 528. - Оп. 1. - Д. 297.

28. Стенографические отчеты заседаний Петербургского общества архитекторов. 1909 г. // ЦГИА СПб. - Ф. 528. - Оп. 1. - Д. 300.

29. Степанов, В. В. А.Е. Белогруд/ В. В. Степанов. - Л. : Изд. Ленингр. отделения Союза Советских Архитекторов, 1939. - 22 с.

30. Турковский С.Я.: личное дело // НА РАХ. Ф. 7. - Оп. 4. - Д. 277.

31. Чепель, А. И. Дореволюционные конкурсные проекты художника-архитектора П.П. Светлицкого / А. И. Чепель // Месмахеровские чтения-2015. СПб., 2015. - С. 28-33.

32. Чепель, А. И. Зодчий и педагог: художникархитектор С.Я. Турковский / А. И. Чепель // История Петербурга. - 2011. - 4 (62). - С. 29-34.

33. Чепель, А. И. Об архитекторе А.Л. Лишневском / А. И. Чепель // Невский архив. - 2010. Вып. IX. - С. 163-177.

34. Чепель, А. И. Собственные дома архитектора Лишневского на Петербургской стороне / А. И. Чепель // Открытые слушания «Института Петербурга».-СПб. : [б. и.], 2010. - С. 84-94.

\section{REFERENCES}

1. Arkhitekturno-khudozhestvennyy ezhenedelnik [Architectural and Artistic Weekly], 1914, Oct. 29.

2. Arkhitekturno-khudozhestvenny ezhenedelnik [Architectural and Artistic Weekly], 1915, Aug. 5.

3. Borisova E.A., Kazhdan T.P. Russkaya arkhitektura kontsa XIX-nachala XX veka [Russian Architecture of the late $19^{\text {th }}-$ early $20^{\text {th }}$ Century]. Moscow, Nauka Publ., 1971.239 p.

4. Vedomosti Elisavetgradskogo gorodskogo obshchestvennogo upravleniya [Statements of Urban Public Management of Elisavetgrad], 1895, March 19.

5. Vedomosti Elisavetgradskogo gorodskogo obshchestvennogo upravleniya [Statements of Urban Public Management of Elisavetgrad], 1896, June 5.

6. Vedomosti Elisavetgradskogo gorodskogo obshchestvennogo upravleniya [Statements of Urban Public Management of Elisavetgrad], 1896, Sep. 19.

7. Vedomosti Elisavetgradskogo gorodskogo obshchestvennogo upravleniya [Statements of Urban Public Management of Elisavetgrad], 1897, Apr. 8.

8. Vedomosti Elisavetgradskogo gorodskogo obshchestvennogo upravleniya [Statements of Urban Public Management of Elisavetgrad], 1898, May 5.

9. Vedomosti Elisavetgradskogo gorodskogo obshchestvennogo upravleniya [Statements of Urban Public Management of Elisavetgrad], 1898, Aug. 2.

10. Vedomosti Elisavetgradskogo gorodskogo obshchestvennogo upravleniya [Statements of Urban Public Management of Elisavetgrad], 1901, May 24.

11. Vedomosti Elisavetgradskogo gorodskogo obshchestvennogo upravleniya [Statements of Urban Public Management of Elisavetgrad], 1901, July 1.

12. Vedomosti Elisavetgradskogo gorodskogo obshchestvennogo upravleniya [Statements of Urban Public Management of Elisavetgrad], 1901, July 22.

13. Dom gorodskikh uchrezhdeniy [House of City Offices]. Rossiyskiy gosudarstvennyy istoricheskiy arkhiv [Russian State Historical Archive], F. 1293, Op. 137, D. 31.

14. Kazus I.A. Sovetskaya arkhitektura 1920-h godov: organizatsiya proektirovaniya [Soviet Architecture of the 1920s: the Design Organization]. Moscow, Progress-Traditsiya Publ., 2009. 464 p.

15. Kirikov B.M. Arkhitektura peterburgskogo moderna. Osobnyaki i dokhodnye doma [Architecture of Art Nouveau Period. Detached Houses and Apartment Houses]. Saint Petersburg, Izd-vo zhurn. "Neva", 2003.511 p.

16. Langbard I.G.: lichnoe delo [J.G. Langbard: Personal Records]. Naychny arkhiv Rossiyskoy akademii khudozhestv [Academic Archive of the Russian Academy of Arts], F. 7, Op. 4, D. 132.

17. Lishnevsky A.L.: lichnoe delo [A.L. Lishnevsky: Personal Records]. Rossiyskiy gosudarstvennyy 
istoricheskiy akhiv [Russian State Historical Archive], F. 787, Op. 11. 1888, D. 107.

18. Lishnevsky A.L.: lichnoe delo [A.L. Lishnevsky: Personal Records]. Tsentral-nyy gosudarstvennyy istoricheskiy arkhiv Sankt-Peterburga [Central State Historical Archive of St. Petersburg], F. 513, Op. 164, D. 1020.

19. $M K$ v Pitere [Moscow Komsomol in St. Petersburg], 2015, Sep. 9-16.

20. Ob imushchestve A.L. Lishnevskogo [On the Property of A.L. Lishnevsky]. Tsentral-nyy gosudarstvennyy istoricheskiy arkhiv SanktPeterburga [Central State Historical Archive of St. Petersburg], F. 513, Op. 156, D. 645.

21. O stroitelnykh narusheniyakh vo dvore I.G. Torkacheva [About the Building Violations in the Area of I.G. Torkachev]. Tsentral-nyy gosudarstvennyy istoricheskiy arkhiv Sankt-Peterburga [Central State Historical Archive of St. Petersburg], F. 513, Op. 156, D. 309.

22. Peterburgskiy listok [St. Petersburg Newspaper], 1907, July 10 (23).

23. Ptichnikova G.A. Pragmatizatsiya arkhitekturnoy professii v usloviyakh sovremennogo proektnogo rynka [Pragmatization of Architectural Profession in Today's Market of Architectural Projects]. Arkhitektura $v$ dialoge s chelovekom [Architecture in Dialogue with a Person]. Moscow, 2012, pp. 290-304.

24. Sankt-Peterburgskie vedomosti [St. Petersburg News], 2016, Jan. 22.

25. Svetlitskiy P.P.: lichnoe delo [P.P. Svetlitskiy: Personal Records]. Rossiyskiy gosudarstvennyy istoricheskiy arkhiv [Russian State Historical Archive], F. 789, Op. 12. 1900, D. I-65.

26. Soveshchanie s arkhitektorami Leningrada. 1937 g. [Meeting with the Architects of Leningrad. 1937]. Tsentral-nyy gosudarstvennyy arkhiv SanktPeterburga [Central State Historical Archive of St. Petersburg], F. 7384, Op. 18, D. 293.
27. Stenograficheskie otchety zasedaniy Peterburgskogo obshchestva arkhitektorov. 1908 g. [Verbatim Records of the St. Petersburg Society of Architects Sessions. 1908]. Tsentral-nyy gosudarstvennyy arkhiv Sankt-Peterburga [Central State Historical Archive of St. Petersburg], F. 528, Op. 1, D. 297.

28. Stenograficheskie otchety zasedaniy Peterburgskogo obshchestva arkhitektorov. 1909 g. [Verbatim Records of the St. Petersburg Society of Architects Sessions. 1909]. Tsentral-nyy gosudarstvennyy arkhiv Sankt-Peterburga [Central State Historical Archive of St. Petersburg], F. 528, Op. 1, D. 300 .

29. Stepanov V.V. A.E. Belogrud. Leningrad, 1939. $22 \mathrm{p}$.

30. Turkovskiy S.Ya.: lichnoe delo [S.Ya. Turkovskiy: Personal Records]. Naychnyy arkhiv Rossiyskoy akademii khudozhestv [Scientific Archive of the Russian Academy of Arts], F. 7, Op. 4, D. 277.

31. Chepel A.I. Dorevolyutsionnye konkursnye proekty khudozhnika-arkhitektora P.P. Svetlitskogo [Pre-Revolutionary Competitive Projects by Artist and Architect P. P. Svetlitsky]. Mesmakherovskie cheniya2015 [Readings Dedicated to the M.G. Messmacher. 2015]. Saint Petersburg, 2015, pp. 28-33.

32. Chepel A.I. Zodchiy i pedagog: khudozhnikarkhitektor S.Ya. Turkovskiy [Architect and Teacher: Artist and Architect S.Ya. Turkovsky]. Istoriya Peterburga [History of St. Petersburg], 2011, no. 4 (62), pp. 29-34.

33. Chepel-A.I. Ob arkhitektore A.L. Lishnevskom [About Architect A.L. Lishnevsky]. Nevskiy arkhiv. Vyp. IX. [Neva Archive. Iss. 9]. Saint Petersburg, 2010, pp. 163-177.

34. Chepel A.I. Sobstvennye doma arkhitektora Lishnevskogo na Peterburgskoy storone [A.L. Lishnevsky's Houses in Saint Petersburg]. Otkrytye slushaniya «Instituta Peterburga» [Public Hearings of the St. Petersburg Institute]. Saint Petersburg, 2010, pp. 84-94.

\section{Information About the Autor}

Aleksandr I. Chepel, Candidate of Sciences (History), Associate Professor, Department of History and Culture Studies, State Marine Technical University of Saint Petersburg, Lotsmanskaya St., 3, 190008 Saint Petersburg, Russian Federation, achepel@mail.ru, http://orcid.org/0000-0001-6733-0686

\section{Информация об авторе}

Александр Иванович Чепель, кандидат исторических наук, доцент кафедры истории и культурологии, Санкт-Петербургский государственный морской технический университет, ул. Лоцманская, 3, 190008 г. Санкт-Петербург, Российская Федерация, achepel@mail.ru, http://orcid.org/ 0000-0001-6733-0686 